\title{
LEVANTAMENTO DAS ÁREAS DE PRESERVAÇÃO PERMANENTE E FRAGMENTOS FLORESTAIS DA BACIA HIDROGRÁFICA DO RIBEIRÃO CUIABÁ (SP)
}

\author{
Diogo Laercio Gonçalves ${ }^{1}$ \\ Jullia Prado Gaudêncio ${ }^{2}$ \\ Antonio Cezar Leal ${ }^{3}$
}

\begin{abstract}
RESUMO
O presente trabalho tem como princípio o mapeamento detalhado na escala 1:3.000, da bacia hidrográfica do ribeirão Cuiabá, nos municípios de Teodoro Sampaio e Mirante do Paranapanema no Estado de São Paulo. A metodologia de trabalho envolve a vetorização dos cursos d'água e das planícies de inundação representadas as áreas úmidas nas aerofotografias da EMPLASA de 2010/2011, utilizando o software ArcGIS 10.2. Nesse contexto, pretende-se abordar a importância das Áreas de Preservação Permanente instituídas pela Lei Federal 12.651/2012, além da relevância dos dados para o planejamento e gestão de recursos hídricos, visto seu grande nível detalhamento. Este trabalho faz parte de uma série de estudos, onde está sendo feito todo o mapeamento da UGRHI 22 - Pontal do Paranapanema na mesma escala apresentada neste trabalho, a ideia é que os dados gerados a partir desta pesquisa possa servir não só de base para futuras pesquisas acadêmicas, como também para órgãos oficiais e do Comitê da Bacia Hidrográfica do Pontal do Paranapanema (CBH-PP)
\end{abstract}

PALAVRAS-CHAVE: APP, Mapeamento, Planejamento e Gestão de Bacias Hidrográficas.

\section{REMOVAL OF PERMANENT PRESERVATION AREAS AND FOREST FRAGMENTS OF THE RIVER BASIN OF RIBEIRÃO CUIABÁ (SP)}

\begin{abstract}
This work is the first detailed mapping in scale 1: 3,000, watershed of ribeirão Cuiabá, in the municipalities of Teodoro Sampaio and Mirante do Paranapanema in the state of São Paulo.The methodology involves the vectorization of rivers and floodplains represented in wetlands in aerial photography of 2010/2011 from EMPLASA, using the ArcGIS 10.2 software. In this context, we intend to address the importance of Permanent Preservation Areas established by Federal Law 12,651 / 2012, beyond the relevance of data for planning and management of water resources as its high level detail. This work is part of a series of studies, which is being done all the mapping UGRHI 22 - Pontal do Paranapanema on the scale presented here, the idea is that the data generated from this research can serve not only as a basis for future academic research, but also for official bodies and the Comitê da Bacia Hidrográfica do Pontal do Paranapanema (CBH-PP)
\end{abstract}

KEYWORDS: APP, Mapping, Planning and Watershed Management.

\footnotetext{
${ }^{1}$ Mestrando em Geografia, FCT/UNESP. e-mail: diogolg12@gmail.com

2 Discente de Engenharia Ambiental, FCT/UNESP. e-mail: julliapgaudencio@hotmail.com

${ }^{3}$ Professor Doutor, FCT/UNESP. e-mail: cezarunesp@gmail.com
} 


\section{EXTRACCIÓN DE ÁREAS DE PRESERVACIÓN PERMANENTE Y FRAGMENTOS DE BOSQUE DE LA CUENCA DEL RIBEIRÃO CUIABÁ (SP)}

Este trabajo es el primer mapa detallado a escala 1: 3.000 , cuenca de ribeirão Cuiabá, en los municipios de Teodoro Sampaio y Mirante do Paranapanema en el estado de São Paulo. La metodología consiste en la ectorización de la drenajes y los humedales que se muestra en las aerofotografias de 2010/2011, de EMPLASA utilizando el software ArcGIS 10.2. En este contexto, tenemos la intención de abordar la importancia de áreas de preservación permanente establecido por la Ley Federal 12.651 / 2012, más allá de la pertinencia de los datos para la planificación y gestión de los recursos hídricos como su alto nivel de detalle. Este trabajo es parte de una serie de estudios, donde esta se haciendo todo el mapeo de la UGRHI 22 - Pontal do Paranapanema en la escala que se presenta aquí, la idea es que los datos generados a partir de esta investigación pueden servir no sólo como base para el futuro la investigación académica, sino también por los organismos oficiales y lo Comitê da Bacia Hidrográfica do Pontal do Paranapanema (CBH-PP)

PALABRAS - CLAVE: APP, cartografía, planificación y gestión de cuencas.

\section{INTRODUÇÃO:}

Não é de hoje que os problemas ambientais tem sido o palco central de discussões frente a expansão urbana exacerbada. A sociedade e o consumo inserido no sistema capitalista fez com que, ao longo do tempo, o espaço geográfico e seus recursos naturais fossem desbravados paulatinamente a fim de incorporá-los em sua dinâmica. Todavia, esses recursos que outrora foram julgados como inesgotáveis passaram a ter mais atenção principalmente com a crescente preocupação com o meio-ambiente entre os países mobilizados por ONG's e movimentos sociais frente a ideia do desenvolvimento sustentável.

Neste contexto, o planejamento ambiental surge como uma ferramenta essencial para mitigar os efeitos causados pelo homem sobre a natureza, com o intuito de se discutir novas práticas sustentáveis que visam o aprimoramento da relação sociedade/natureza. A partir deste cenário, a bacia hidrográfica se configura como a principal unidade de planejamento no âmbito das ações socioambientais.

A bacia hidrográfica consiste em uma área geográfica que drena suas águas para um determinado canal fluvial principal. Ela é constituída e dinamizada pelos recursos hídricos, solo, vegetação, meio antrópico e por outros componentes ambientais (MOTA, 2008). Seus limites são bem demarcados geograficamente, por isso, a mesma é considerada uma unidade territorial ideal, em que toda e qualquer interferência natural ou antrópica influencia na quantidade e qualidade do recurso hídrico. 
Uma das formas de garantir o equilíbrio da dinâmica de uma bacia hidrográfica é preservar a vegetação em locais críticos, tais como os entornos do canal, encostas, restingas, manguezais e topos de morros. Tal proteção garante maior estabilidade e resiliência dos corpos d'agua e do solo diante de alguma interferência natural ou artificial.

Para entender como a vegetação realiza tal proteção, toma-se como exemplo as matas ciliares, que interceptam a água da chuva, encaminhando-a mais suavemente ao solo. Como este está protegido e permeado pelas raízes das plantas, permanece poroso, com alta capacidade de absorção. Então, ao contrário de deslizar sobre a superfície do solo, a água penetra, realimentando os lençóis freáticos. (MUELLER, 1998)

As Áreas de Preservação Permanente são de suma importância para a manutenção dos nossos mananciais. Entretanto no Brasil, o debate em torno da importância das APPs para a garantia da produtividade da terra gera muitas polêmicas sobre a área a ser protegida. Assim grande parte delas não estão preservadas, causando uma série de problemas à drenagem de uma bacia hidrográfica, tais como: assoreamento do canal fluvial, aumento da erosão, diminuição da permeabilidade do solo e a consequentemente a perda de nutrientes do mesmo.

No presente trabalho foi estudada a bacia do ribeirão Cuiabá, localizado no extremo leste de Teodoro Sampaio, próximo ao seu perímetro urbano e que marca limite entre esse município e Mirante do Paranapanema.

A economia desses municípios é baseada na agropecuária (cana-de-açúcar e bovinos), na produção de cana-de-açúcar, etanol e comércio. Além disso, Teodoro Sampaio possui, dentro de sua área, o parque estadual Morro do Diabo, que fica a $11 \mathrm{~km}$ leste do centro da cidade. Com 33.845,33 hectares e um pico de 599,5 metros, o parque estadual preserva o que sobrou da vegetação nativa da Mata Atlântica do Interior (IBGE, 2010)

A bacia hidrográfica do ribeirão Cuiabá fica próxima ao Morro do Diabo (Figura 1), e possui uma área altamente preservada em seu entorno. Em compensação, as APPs que margeiam o canal fluvial principal e seus tributários não estão, em sua maioria, preservadas. 
Os estudos dessa bacia, fazem parte do mapeamento na escala 1:3.000, que está sendo realizado para toda a UGRHI 22 - Pontal do Paranapanema pelo Grupo de Pesquisa Gestão Ambiental e Dinâmica Socioespacial (GADIS) da FCT/UNESP, em parceria com o Núcleo de Estudos Ambientais e Geoprocessamento (NEAGEO) da UNOESTE ambas universidades de Presidente Prudente-SP

Figura 1 - Localização da Bacia Hidrográfica do Ribeirão Cuiabá

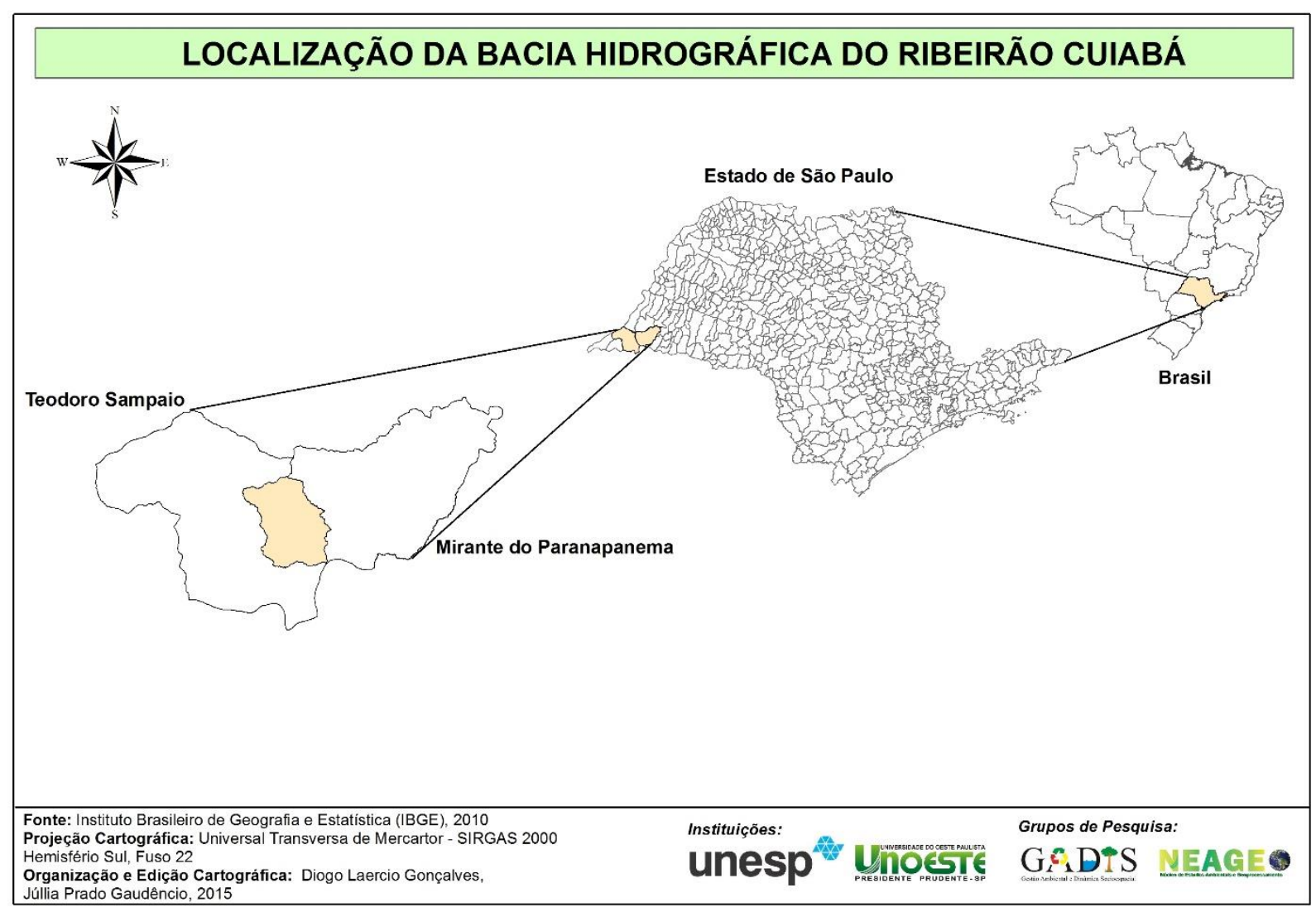

\section{OBJETIVOS}

Este trabalho tem como objetivo principal demonstrar o levantamento das áreas de preservação permanente e fragmentos florestais da bacia hidrográfica do ribeirão Cuiabá nos municípios de Teodoro Sampaio e Mirante do Paranapanema, a partir do mapeamento em detalhe (escala de trabalho 1:3.000), utilizando as ortofotografias aéreas da EMPLASA, identificando os canais fluviais e as áreas 
úmidas, com o intuito de gerar um mapa de APP que possa representar a área ideal a ser protegida deste manancial.

\section{METODOLOGIA}

Para o desenvolvimento da pesquisa, inicialmente elaborou-se um levantamento bibliográfico prévio, sobre temas pertinentes ao estudo, tais como bacias hidrográficas, áreas de preservação permanente, geomorfologia fluvial, dentre outros. Também foram revisadas bases cartográficas mais antigas da área tais como IBGE (1976) e IGC (1998), com o intuito de facilitar a compreensão das áreas a serem mapeadas.

Neste contexto, buscou-se montar uma base cartográfica que fornecesse o suporte necessário para o mapeamento da área na escala de detalhe de 1:3.000. Para isso, foram utilizados o levantamento aerofotogramétrico realizado pela Empresa Paulista de Planejamento Metropolitano (EMPLASA), realizado entre os anos de 2010 e 2011, com resolução espacial de 1 metro. Além disso, foram utilizadas como auxílio, as imagens de radar SRTM, para a criação de um modelo digital de elevação no formato de relevo sombreado (hillshade)

Após esta etapa, os dados foram sistematizados no SIG ArcGIS 10.2, onde se desenvolveu o mapeamento dos cursos d'água e áreas úmidas na escala 1:3.000. A partir dos vetores foi possível construir o mapa das Áreas de Preservação Permanente (APP), com o uso da ferramenta Geoprocessing/buffer. Como complementação a análise espacial da bacia, foram também vetorizadas as áreas de fragmentos florestais e reservas legais, além da área do Parque Estadual Morro do Diabo

\section{RESULTADOS E DISCUSSÕES}

As Áreas de Preservação Permanente (APP) são áreas onde a vegetação deve ser mantida intacta, tendo como objetivo garantir a preservação dos recursos hídricos, a estabilidade da biodiversidade, além do o bem-estar da população (ARAÚJO, 2002). 
A preservação dessas áreas torna-se vital para o funcionamento da bacia hidrográfica como um todo, tanto que existe uma legislação específica no Brasil, que garante a preservação dessas áreas, pela Lei ㄲo12.652, de 25 de maio de 2012, a qual define que APP consistem em:

[...] área protegida, coberta ou não por vegetação nativa, com a função ambiental de preservar os recursos hídricos, a paisagem, a estabilidade geológica e a biodiversidade, facilitar o fluxo gênico de fauna e flora, proteger o solo e assegurar o bem-estar das populações humanas. (BRASIL, 2012)

A delimitação da área a ser protegida dentro da bacia hidrográfica, vai de acordo com a classificação do curso d'água a partir de sua metragem, definidos a

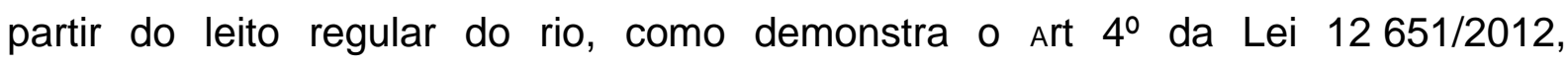
apresentado a seguir:

Art. 4ำ Considera-se Área de Preservação Permanente, em zonas rurais ou urbanas, para os efeitos desta Lei:

I - as faixas marginais de qualquer curso d'água natural perene e intermitente, excluídos os efêmeros, desde a borda da calha do leito regular, em largura mínima de: (Incluído pela Lei no 12.727, de 2012).

a) 30 (trinta) metros, para os cursos d'água de menos de 10 (dez) metros de largura;

b) 50 (cinquenta) metros, para os cursos d'água que tenham de 10 (dez) a 50 (cinquenta) metros de largura;

c) 100 (cem) metros, para os cursos d'água que tenham de 50 (cinquenta) a 200 (duzentos) metros de largura;

d) 200 (duzentos) metros, para os cursos d'água que tenham de 200 (duzentos) a 600 (seiscentos) metros de largura;

e) 500 (quinhentos) metros, para os cursos d'água que tenham largura superior a 600 (seiscentos) metros;

Todavia, esta metragem desconsidera um dos elementos fundamentais para a manutenção dos cursos d'água nas bacias hidrográficas que são as planícies de inundação, popularmente conhecidas como "várzeas". Essas áreas, representam a forma mais comum de deposição e sedimentação fluvial. Sua formação é constituída a partir de aluviões e por vários materiais depositados dentro ou fora do canal fluvial. (CHRISTOFOLETTI, 1980). 
As áreas de planícies de inundação apresentam várias formas de erosão e deposição como demonstra o quadro e a figura a seguir:

Quadro 1 - Formas de erosão e deposição encontradas nas planícies de inundação

\begin{tabular}{|c|c|}
\hline FORMA & DESCRIÇÃO \\
\hline Terraço Fluvial & $\begin{array}{l}\text { Terraço construído por aluviões antigos e topograficamente mais elevado } \\
\text { do que a planície ativa atual; representa um testemunho do processo de } \\
\text { evolução da planície. }\end{array}$ \\
\hline Dique Marginal & $\begin{array}{l}\text { Depósito estreito formado nas margens do canal durante o período de } \\
\text { inundação, devido à disposição de sedimentos. Os diques são os pontos } \\
\text { mais elevados da planície ativa. }\end{array}$ \\
\hline Ilha & $\begin{array}{l}\text { Depósitos do centro do canal que se formam pela redução de competência } \\
\text { do rio. }\end{array}$ \\
\hline Margem & $\begin{array}{l}\text { Limite lateral do canal fluvial caracterizado pela presença de regiões de } \\
\text { erosão ativa ou deposição ativa. }\end{array}$ \\
\hline Paleodique & $\begin{array}{l}\text { Remanescente mais elevado que representa o testemunho do local de } \\
\text { escoamento de um canal fluvial em uma paleoplanície. }\end{array}$ \\
\hline Planalto & $\begin{array}{l}\text { Região extrema à planície e não sujeita a inundação mesmo em períodos } \\
\text { de cheia excepcional. }\end{array}$ \\
\hline $\begin{array}{l}\text { Talvegue - Canal } \\
\text { Principal }\end{array}$ & Região mais profunda do canal que se estende da nascente à foz. \\
\hline $\begin{array}{l}\text { Talvegue - Canal } \\
\text { Secundário (paraná) }\end{array}$ & $\begin{array}{l}\text { Região profunda de um canal secundário formado em alguns segmentos } \\
\text { da planície em decorrência de variações de competência fluvial. }\end{array}$ \\
\hline Canal Temporário & $\begin{array}{l}\text { Região profunda de um canal temporário que liga bacias de inundação ao } \\
\text { canal principal ou secundário }\end{array}$ \\
\hline Lodaçal & $\begin{array}{l}\text { Região de aluviões finos resultantes do extravasamento excepcional dos } \\
\text { rios - paleoplanícies. }\end{array}$ \\
\hline $\begin{array}{l}\text { Bacias de } \\
\text { Inundação }\end{array}$ & $\begin{array}{l}\text { Região a montante dos diques marginais ativos que recebe o excesso de } \\
\text { água e sedimentos nas enchentes normais da planície ativa. }\end{array}$ \\
\hline Depósito de canal & $\begin{array}{l}\text { Depósitos temporários ou permanentes no talvegue ou no canal de } \\
\text { margens plenas que se torna emerso durante o período de vazante. }\end{array}$ \\
\hline $\begin{array}{l}\text { Nível de inundação } \\
\text { de margens plenas } \\
\text { (bankfull discharge) }\end{array}$ & $\begin{array}{l}\text { Nível de inundação até o nível de erosão ativa das margens do canal. } \\
\text { Limite de ocupação por vegetação de forma perene, mesmo que inundada. } \\
\text { Nível de fluxo de inundação dominante no canal em períodos de } \\
\text { recorrência de } 1 \text { a } 2 \text { anos. }\end{array}$ \\
\hline $\begin{array}{l}\text { Nível de inundação } \\
\text { excepcional }\end{array}$ & $\begin{array}{l}\text { Nível de inundação de baixa frequência (entre três e quatro vezes por } \\
\text { século). }\end{array}$ \\
\hline Nível mínimo normal & Nível mínimo com intervalo de recorrência de 1 a 2 anos. \\
\hline $\begin{array}{l}\text { Nível mínimo } \\
\text { excepcional }\end{array}$ & Nível mínimo de baixa frequência (entre três e quatro vezes por século). \\
\hline
\end{tabular}

Fonte: MOORE (1967); CHRISTOFOLETTI (1981); GUERRA, A. T. E GUERRA A. J. T. (1997). Org.: NOVO (2008). Extraído de FLORENZANO (2008)

A preservação dessas áreas de planícies aluviais é de grande importância, visto que em episódios de chuvas mais intensas essas áreas são ocupadas pelo canal fluvial tornando-se seu leito. Portanto, a proposta de mapeamento das áreas 
de planícies aluviais torna-se uma ferramenta essencial para o planejamento ambiental, não só apenas da bacia do ribeirão Cuiabá, mas como todas as bacias hidrográficas no geral.

Para o mapeamento da bacia criou-se um arquivo shapefile no ArcCatalog no formato de polígono (polygon) para o curso d'água, e outro para as áreas úmidas, representando as áreas de planícies aluviai, com o intuito de abranger toda a área tanto do canal fluvial, quanto do leito maior sazonal. No processo de vetorização observou-se as feições visuais dos elementos da bacia, a declividade, por meio das curvas de nível, a presença de vegetação e de alguns focos de processos erosivos.

Considerou-se o curso d'água como um canal de coloração escura, estreito e sinuoso no alto e no médio curso, e de coloração mais clara e com perfil mais largo à medida que vai se aproximando do ponto exutório, no baixo curso.

Já as áreas úmidas foram consideradas as feições mais escuras da bacia, próximas ao canal fluvial, nas áreas de planícies aluviais com a ausência de vegetação mais densa, tais como as florestas, e com a presença de vegetação úmida, por exemplo, a taboa e o capim-rabo-de-burro. Essas feições caracterizam o leito maior sazonal do ribeirão.

A seguir, pode-se observar uma parte da vetorização do curso d'água no baixo curso, em azul (Figura 2), e uma parte das áreas úmidas, em vermelho (Figura 3).

Figura 2 - Vetorização do curso d'água (azul)

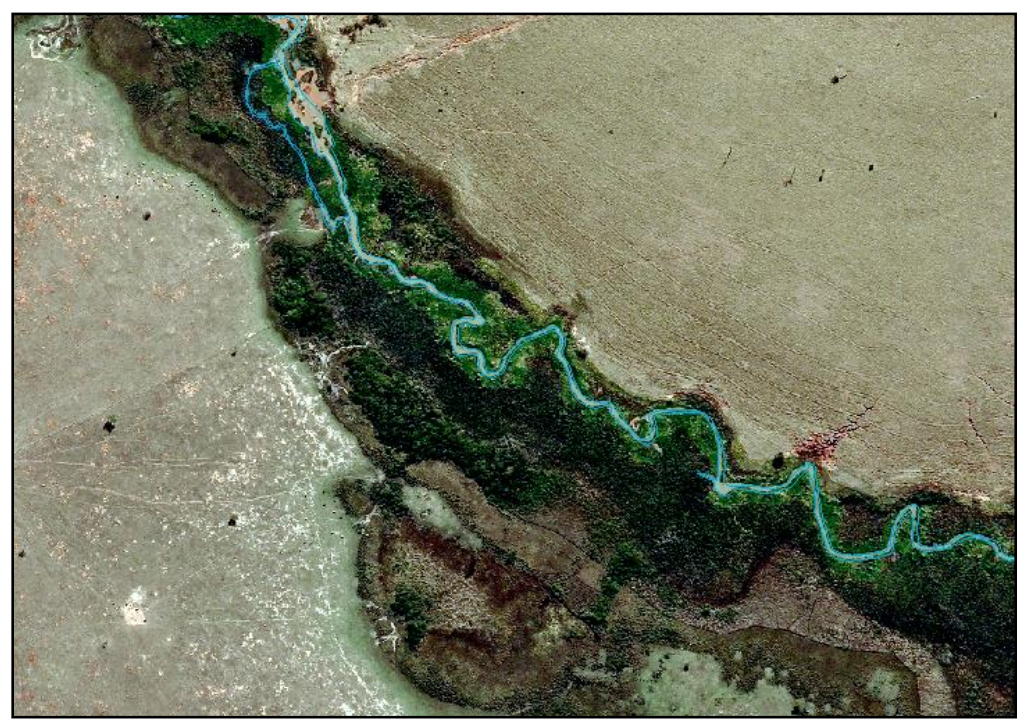

Fonte: ArcGIS 10.2. Tirada em 28 maio 2015 
Figura 3 - Vetorização da área úmida (vermelho)

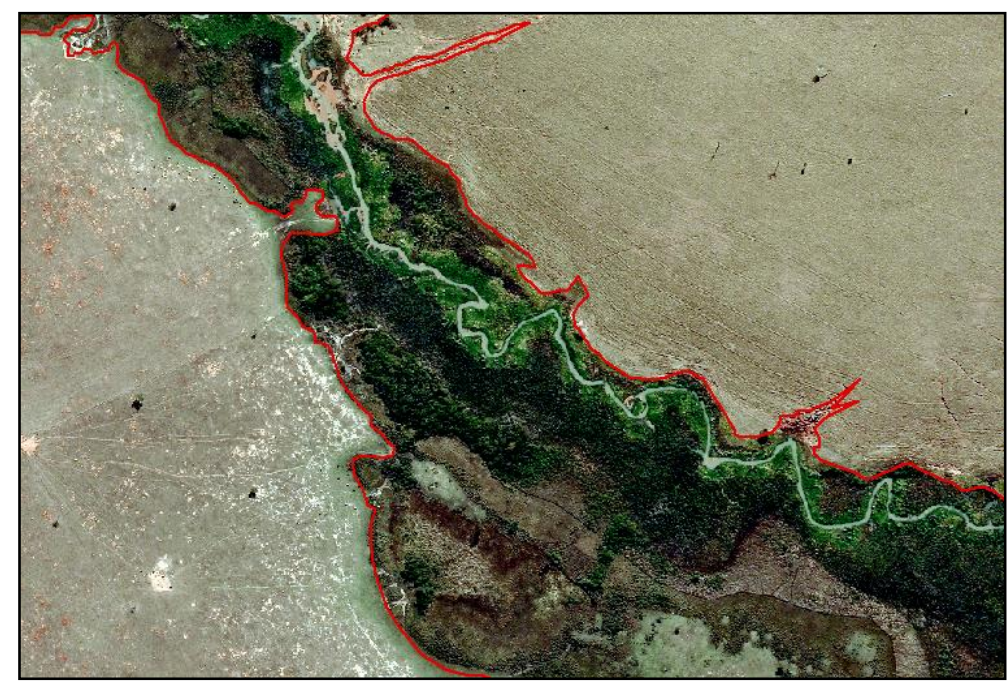

Fonte: ArcGIS 10.2. Tirada em 28 maio 2015

Para complementação da caracterização ambiental da bacia também foram vetorizadas áreas de fragmentos florestais e reservas legais, bem como o trecho do Parque Estadual Morro do Diabo.

Figura 4 - Vetorização dos fragmentos florestais e reservas legais (vermelho), Parque Estadual Morro do Diabo (amarelo) e Curso D’água e áreas úmidas (azul).

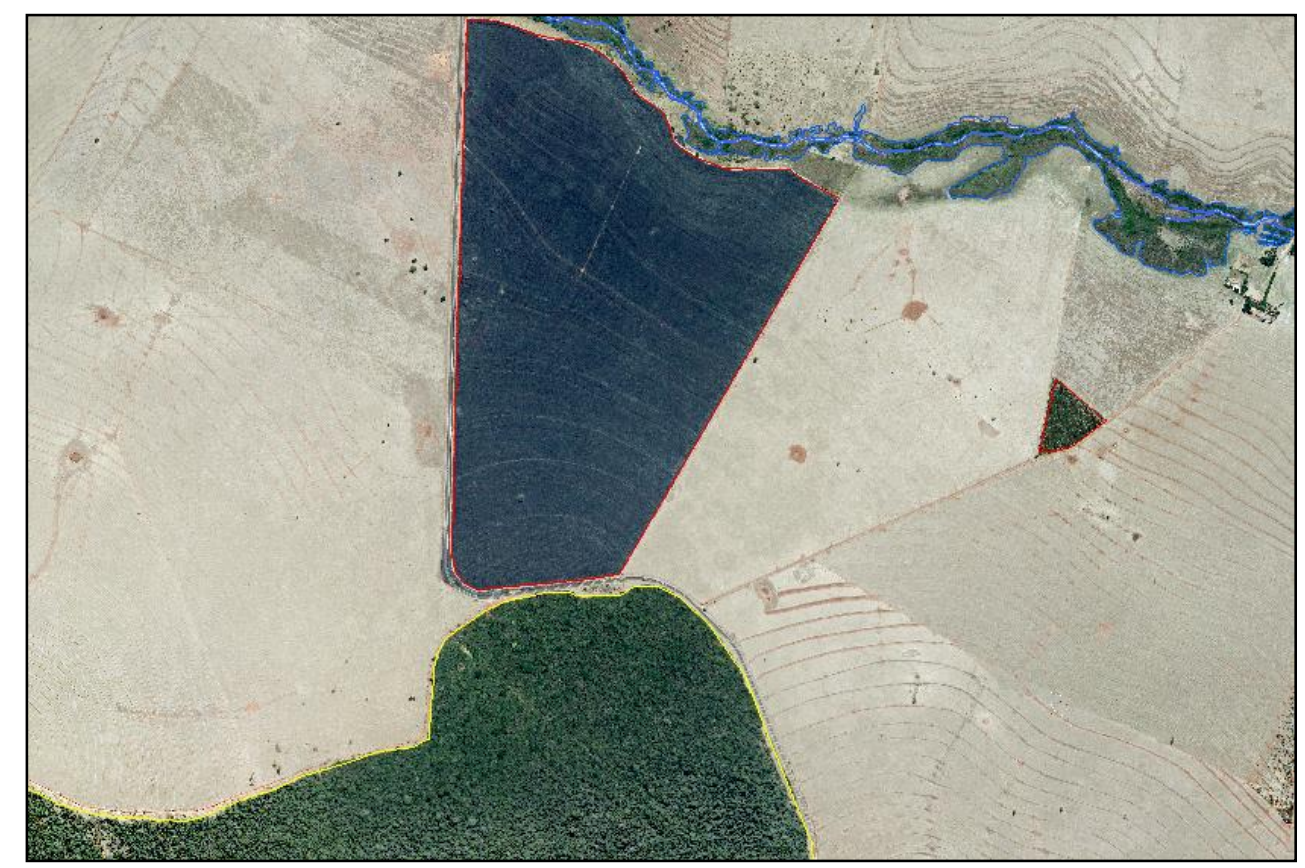

Fonte: ArcGIS 10.2. Tirada em 28 maio 2015 
Para a delimitação das APP utilizou-se a ferramenta geoprocessing/buffer. Como nenhum ponto da bacia ultrapassou 10 metros, a Área de Preservação Permanente no entorno do curso d'água corresponde a 30 metros. Contudo, foi utilizado o shapefile de áreas úmidas (planícies de inundação) para gerar o arquivo final a partir do nível mais alto (leito maior sazonal) ocupado pelo rio em episódios de cheias recorrentes em intervalos de 1 ou 2 anos.

De acordo com Boin (2005) apud Jardim (2009), as planícies aluviais constituem uma faixa de largura variável ao longo dos rios o que forma a planície de inundação. É nesta área que está envolvida dois períodos distintos, a vazante (período de menor volume d'água) e a enchente, período onde as águas transbordam para a planície de inundação (Figura 5). É a partir desta característica natural entre enchente e vazante, que o ecossistema de várzea apresenta sua unicidade.

Figura 5 - Esquema geral de um ecossistema de várzea

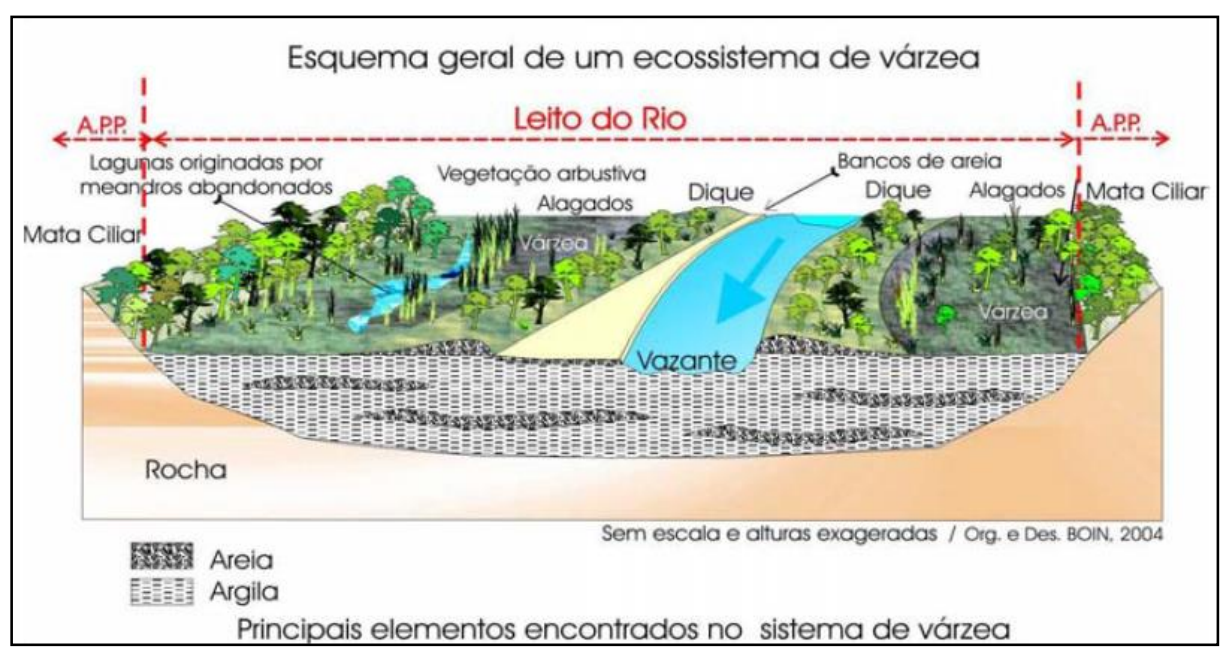

Fonte: Boin (2004)

Embora, não previsto pela Lei 12.651/2012, na qual afirma que área a ser protegida deve estar desde a borda da calha do leito regular, a preservação dessas áreas é importante, visto que fazem parte do próprio regime hidrológico da bacia.

Com a alteração do Código Florestal Brasileiro em 2012, suprimiu-se a necessidade de ser proteger essas áreas como apresentado nas leis anteriores: Lei 4.771/65 (antigo Código Florestal Brasileiro) e Lei 7.803/89 a qual complementava a lei anterior destinando como Área de Preservação Permanente ao longo dos rios 
ou de qualquer curso d'água desde o seu nível mais alto em faixa marginal (BRASIL, 1989).

Por esse motivo optou-se neste trabalho a criação da Área de Preservação Permanente a partir do nível mais alto do rio, representados pelas áreas úmidas porém, mantendo a metragem de 30 metros tendo em vista a largura regular do canal que não chega a 10 metros.

Após essa etapa, também foi gerado um shapefile de pontos (point) para demarcar as nascentes ao longo da Bacia Hidrográfica do Ribeirão Cuiabá. Ao todo foram encontradas 15 nascentes, de acordo com a Lei Federal 12.651/2012 no artigo $4^{\circ}$ as nascentes possuem uma delimitação específica:

IV - as áreas no entorno das nascentes e dos olhos d'água perenes, qualquer que seja sua situação topográfica, no raio mínimo de 50 (cinquenta) metros;

Neste contexto, foram gerados as APP das nascentes utilizando também a ferramenta geoprocessing/buffer, só que utilizando a metragem de 50 metros estabelecidas pela Lei 12.651/2012. Realizadas todas as etapas abaixo apresentamos o resultado final do mapeamento da bacia hidrográfica do ribeirão Cuiabá. 
Figura 6 - Levantamento das APPs e Fragmentos Florestais da bacia

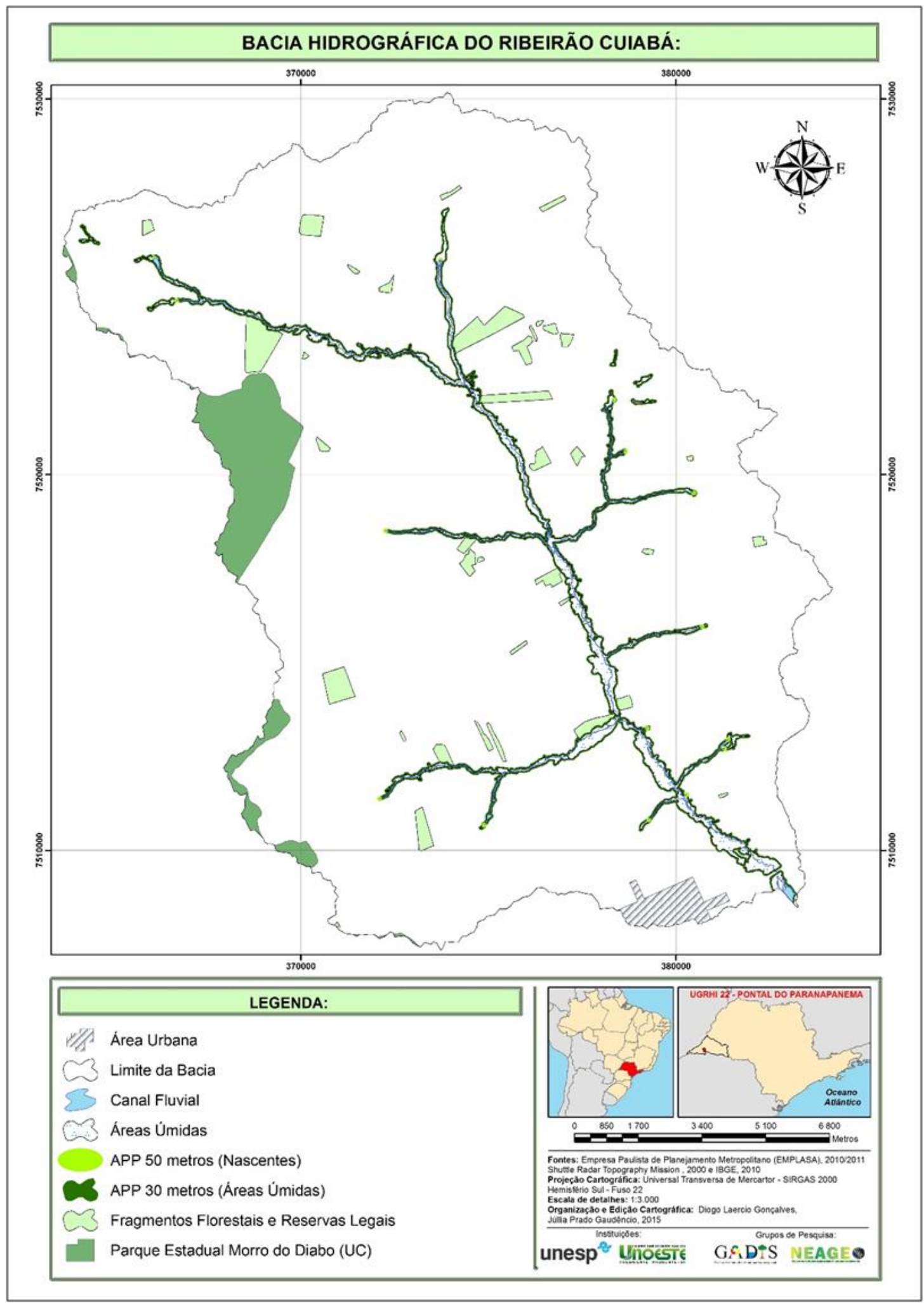




\section{CONSIDERAÇÕES FINAIS}

As ferramentas dos SIG contribuem a ter uma melhor visão e representação dos dados espaciais, fundamentalmente essenciais para o planejamento e gestão de recursos hídricos. A argumentação de acordo com a legislação ambiental brasileira é importante para que estas áreas possam ser, de fato, preservadas.

Ao longo da bacia hidrográfica do ribeirão Cuiabá podemos perceber a partir das fotografias aéreas que embora apresente uma quantidade significativa de fragmentos florestais, a conectividade entre os mesmos é baixa, isso se estende também para sua conectividade com o Parque Estadual Morro do Diabo, principal Unidade de Conservação da UGRHI 22 - Pontal do Paranapanema.

A conectividade entre as Áreas de Preservação Permanente e as Unidades de Conservação é de extrema importância, frente a manutenção da fauna e flora local. Sem ela, nossas espécies correm sério risco de extinção como no caso do Mico-Leão Preto, onde seu principal habitat encontra-se no parque. Por isso, esta bacia apresenta uma grande importância por se tratar de uma área que ocupa além de uma parte do parque, suas principais áreas de entorno.

Além disso, as APPs presentam um grande potencial para a proteção dos recursos hídricos locais evitando o foco de processos erosivos e contribuindo para a manutenção dos mananciais, o que nos remete a um estudo amplo que está sendo realizado para todo a UGRHI 22 - Pontal do Paranapanema, no qual este trabalho faz parte.

O mapeamento na escala 1:3.000 representa um avanço na questão do detalhamento das pesquisas para a o planejamento e gestão dos recursos hídricos, nosso intuito é utilizar esses dados como base de trabalhos tanto no âmbito acadêmico como também para órgãos oficiais, comitês de bacias hidrográficas, de modo a contribuir perante a sociedade em prol do desenvolvimento sustentável. 


\section{REFERÊNCIAS BIBLIOGRÁFICAS:}

ARAÚJO, S.M.V.G.; As áreas de Preservação Permanente e a questão urbana; Consultoria Legislativa da Câmara dos Deputados, Brasília, 2002.

BRASIL, Lei Federal ํำ12.651, de 25 de maio de 2012. Dispõe sobre a proteção da vegetação nativa, Brasília, 2012

BRASIL, Lei Federal ํ 4.771, 15 de setembro de 1965. Institui o novo Código Florestal, Brasília, 1965

BRASIL, Lei Federal o 7.803 de 18 de julho de 1989. Altera a redação da Lei no 4.771, de 15 de setembro de 1965, e revoga as Leis nos 6.535, de 15 de junho de 1978, e 7.511, de 7 de julho de 1986. Brasília, 1989.

CHRISTOFOLETTI, A. Geomorfologia. 2ª Edição. São Paulo: Edgard Blücher, 1980.

HORTON, R.E. Erosinal development of streams and their drainage basins: hirophysical approach to quantitative morphology. Bulletin of the Geological Society of America, 1945. Disponível em <http://gsabulletin.gsapubs.org/content/56/3/275.short> Acesso em 26 maio. 15

INSTITUTO BRASILEIRO DE GEOGRAFIA E ESTATÍSTICA (IBGE), Cidades, Teodoro Sampaio, São Paulo. Disponível em <http://www.cidades.ibge.gov.br/xtras/perfil.php?lang=\&codmun=355430\&search=||infogr\%E1ficos:informa\%E7\%F5es-completas> Acesso em 27 maio 2015.

JARDIM, Fernando Henrique Camargo - "Geoprocessamento aplicado à Análise Ambiental do Município de Rosana e definição dos impactos sofridos nas Áreas de Preservação Permanente com a construção das Usinas Hidrelétricas" - Trabalho de Conclusão de Curso de Engenharia Ambiental, Universidade do Oeste Paulista (UNOESTE), Presidente Prudente, 2009.

MOTA, Suetônio - "Gestão Ambiental de Recursos Hídricos" - Rio de Janeiro: ABES, 2008.

MUELLER, C. C. Gestão de matas ciliares. In: LOPES, I. V.; BASTOS FILHO, G. S.; KANEVIESKIR, T. KANEVIESKIR, T.C. Produtores de água na Microbacia do Manancial Córrego do Veado Presidente Venceslau, São Paulo: Potencialidades em Questão. Presidente Prudente, 2011. Disponível em <http://bacias.fct.unesp.br/gadis/docs/publicaco. s/11_thici_thisla.pdf> Acesso em 27 maio 2015

NOVO, Evlyn Márcia L. de M. Ambientes Fluviais - In: FLORENZANO, Teresa G -Geomorfologia: Conceitos e Tecnologias Atuais. Editora Oficina de Textos, 2008 